\title{
LAS ESTRATEGIAS DEL CREER EN LOS OCHO MÁS ODIADOS, DE QUENTIN TARANTINO
}

\author{
Alejandro Núñez Alberca* \\ Universidad de Lima, Perú \\ aalbercad@gmail.com
}

Recibido: 31/5/2020 Aceptado: 17/7/2020

DOI: https://doi.org/10.26439/contratexto2020.n034.4875

Resumen. El presente artículo propone un análisis semiótico-estructural de la película de Quentin Tarantino Los ocho más odiados (The Hateful Eight, 2015). Nuestro trabajo incorpora elementos provenientes de la narratología fílmica, en particular la idea del unreliable narrator de Emily Anderson, quien plantea la posibilidad de un narrador no confiable al interior del discurso. El análisis demuestra que el filme, tanto al nivel del relato como del discurso, presenta una serie de simulacros manipulatorios que les permiten a sus actantes organizar la dimensión cognitiva del saber y el creer. Se revela un dispositivo que no solo permite a los personajes engañar a otros con sus discursos, sino también al enunciador que opera en un nivel superior. De este modo, el filme convierte la subinformación y la contrainformación en sus instrumentos clave.

Palabras clave: semiótica / narratología / creencia / The Hateful Eight / Quentin Tarantino

\section{THE STRATEGIES OF BELIEF IN QUENTIN TARANTINO'S THE HATEFUL EIGHT}

Abstract. This article proposes a semiotic-structural analysis of Quentin Tarantino's film The Hateful Eight (2015). Our work incorporates elements from filmic narratology, in particular the idea of Emily Anderson's unreliable narrator, who considers the possibility of an overall unreliable discourse. Our analysis shows that the film, both at the narrative and discourse level, presents a series of manipulative simulations that allow its actants to organize the cognitive dimension of knowledge and belief. This reveals a device that allows characters to deceive not only others with their speeches but also the enunciator who operates at a higher level. Therefore, the film transforms the underreporting and misreporting into its key tools.

Keywords: semiotics; narratology / belief; The Hateful Eight / Quentin Tarantino

* Bachiller en Comunicación por la Universidad de Lima, Perú (véase https://orcid.org/0000-0002-5033-8283). 


\section{AS ESTRATÉGIAS DE CRENÇA EM OS OITO ODIADOS, DE QUENTIN TARANTINO}

Resumo. 0 presente artigo propõe uma análise semiótico-estrutural do filme de Quentin Tarantino Os oito odiados (The Hateful Eight, 2015). Nosso trabalho incorpora elementos da narratologia fílmica, em particular a ideia do unrealiable narrator de Emily Anderson, que propõe a possibilidade de um narrador não confiável no discurso. Nossa análise demonstra que o filme apresenta, tanto no nível da narrativa quanto do próprio discurso, uma série de simulações manipulativas que permitem que seus actantes organizem a dimensão cognitiva do conhecimento e da crença. Isso revela um dispositivo que não permite apenas que os personagens enganem os outros com seus discursos, mas também o próprio enunciador que opera em um nível superior. Dessa maneira, o filme transforma as sub-informações e as contra-informações em seus principais instrumentos.

Palavras-chave: semiótica / narratologia / crença / The Hateful Eight / Quentin Tarantino 


\section{INTRODUCCIÓN}

La creencia supone, para la semiótica discursiva, una dimensión ineludible del discurso, ya sea que hablemos a los actantes de la enunciación implícita como a aquellos manifestados en la dimensión del relato. Para Greimas (1989), el enunciador está emancipado de la necesidad de referirse a una dimensión empírica extradiscursiva. Su hacer se dirige a lograr la adhesión de su contraparte semiolingüística, es decir, el enunciatario. La creencia, no obstante, comparte un mismo universo cognitivo con el ámbito del saber, y la compleja relación que ambos mantienen entre sí se hace evidente en discursos de índole audiovisual (Gaudreault y Jost, 1995). Es en estos relatos donde nos vemos obligados a sopesar la inclusión de la cámara como dispositivo de la visión, asumiendo la complejidad que ello acarrea para el proceso de enunciación.

El presente artículo analiza la complejidad de esta dimensión cognitiva del discurso, para lo cual se ha elegido como objeto de estudio una película puntual: el wéstern revisionista Los ocho más odiados (The Hateful Eight, 2015), de Quentin Tarantino. La trama consiste en aproximadamente un día en la vida de un grupo de desconocidos en el oeste de Estados Unidos, doce años luego de la guerra civil. El mercenario John Ruth se ha encadenado a la fugitiva Daisy Domergue, y se dispone a llevarla a la ciudad de Red Rock para entregarla al verdugo. En el camino, su diligencia recoge al exoficial de caballería Marquis Warren, quien ahora es un mercenario al servicio de la ley, y a Chris Mannix, un exrebelde de la Confederación que afirma ser el nuevo sheriff de Red Rock. Refugiándose de una tormenta, el grupo se detiene en un puesto de descanso llamado la Mercería de Minnie, donde pretenden pasar la noche. A medida que se instalan, caen en la cuenta de que los otros inquilinos no son lo que aparentan; al menos uno de ellos es un cómplice de Domergue, dispuesto a lo que sea para salvarla del patíbulo.

\section{LA DIMENSIÓN DEL SABER Y EL CREER EN SEMIÓTICA Y NARRATOLOGÍA}

La semiótica discursiva traza una línea muy clara entre verosimilitud y veridicción. En Del sentido II (1989), Greimas discute estas categorías: la primera invoca la realidad extradiscursiva, aquello que cada grupo social establece como verdadero según criterios culturales e históricos específicos. De esta forma, aprehender la "realidad" es adherirse al sentido común dictaminado por el grupo. Ante esto, el autor introduce la categoría de veridicción, que describe "el marco donde se ejerce la actividad cognoscitiva de naturaleza epistémica, que, mediante diferentes programas modales, trata de alcanzar una posición veridictoria, capaz de ser sancionada por un juicio epistémico definitivo" (Greimas y Courtés, 1990, p. 434). De esta forma, se restablece la autonomía del discurso respecto a los estados de cosas; la pregunta ya no se dirige a la verdad en un sentido ontológico, sino al parecer-ser de la verdad como efecto de sentido del propio discurso, lugar donde se inscriben lo verdadero, lo falso, la ilusión y el secreto, a partir 
de lo que denomina marcas de veridicción. Por otro lado, se asume que toda comunicación humana parte de un contrato de naturaleza fiduciaria entre los actantes de la enunciación, quienes están implicados en él. El primero, el enunciador, como manipulador; el segundo, el enunciatario, garante de un hacer interpretativo que evalúa a cada instante del proceso manipulatorio (Greimas, 1989). A partir de la categoría semántica [ser $\leftrightarrow$ parecer], se obtiene el cuadrado semiótico resultante:

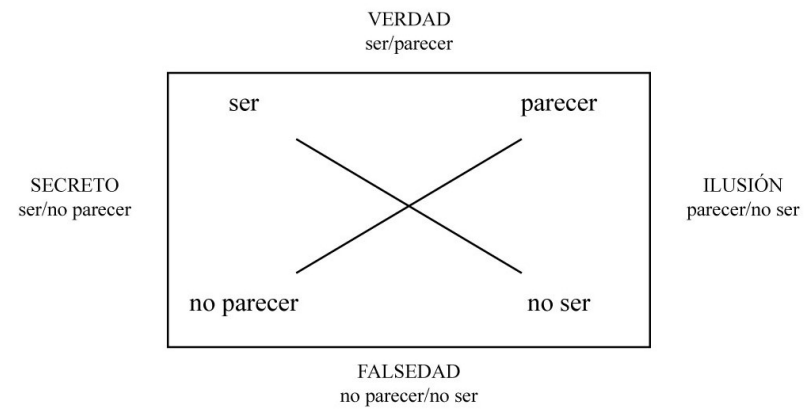

Figura 1. Cuadrado semiótico de la veridicción

Fuente: Greimas y Courtés (1990)

La importancia de la noción greimasiana de la creencia no termina ahí, claro está. Fontanille y Zilberberg (2004) vinculan el creer como resorte fundamental de las competencias modales, es decir, una modalidad primigenia anclada en la fiducia del actante-sujeto respecto a sus propias capacidades. El creer se acopla a cada una de las modalidades de base. Si el actante se halla modalizado por el deber, el poder, el saber o el querer, ello solo es posible en tanto él cree que debe, cree que puede, o bien cree que sabe y cree que quiere.

La preocupación por la dimensión cognitiva del saber y el creer también está presente en la narratología fílmica. En su texto clásico, Stam, Burgoyne y Flitterman-Lewis (1999) definen la narración como "la actividad discursiva responsable de representar o relatar los hechos o situaciones de la historia" (p. 128), aproximándose con esto a autores como Branigan (1992), Bordwell (1996), Prósper Ribes (2013) o García-Noblejas (1983), quienes ya relacionaban el acto narrativo con un proceso informacional, tomando "las acciones humanas como objeto de la enunciación" (García-Noblejas, 1983, p. 466). Tan pronto el espectador asume el rol de narratario (actualización narrativa del enunciatario), el sintagma audiovisual aparece como mediación necesaria entre él y aquella otra instancia que es el narrador fílmico. Apoyado en las ideas de Christian Metz, Gómez Tarín (2008) escribe que "lo que ve el espectador, lo ve por delegación, es consciente de la ficción al tiempo que puede apropiarse de ella" (p. 7). El autor remite el origen de este proceso a un 
sujeto de la enunciación, mientras que, desde una perspectiva propiamente semiótica, es preferible el término instancia de enunciación, utilizado para designar el dispositivo a cargo del proceso de generación discursiva, el cual es siempre presupuesto y se infiere como "efecto [de sentido] del enunciado" (Blanco, 2018, p. 290). La enunciación, como tal, es inseparable de los actantes enunciador y enunciatario', los cuales, aunque carezcan de una existencia figurativa en el enunciado, no pueden no estar comprendidos en él. En breve, si la enunciación como tal es siempre presupuesta, los actantes que la articulan deben serlo también.

Es evidente que las operaciones del enunciador sobrepasan con creces las marcas discursivas aparentes. Se extienden para incluir la dimensión cognoscitiva del relato y el proceso mismo de narración, si es que por ello entendemos no solo los acontecimientos, sino su disposición ordenada en el discurso (Gaudreault y Jost, 1995; Metz, 2002; Prósper Ribes, 1991, 2013). Por su parte, Casetti (1996) manifiesta que el narrador no es otra cosa que la figuración del enunciador, la especificidad narrativa del actante semiolingüístico que, por lo demás, permanece ausente. El narrador, si es que lo hay, es un primer actante desembragado de la instancia de enunciación (Blanco, 2012, 2018). Esta diferenciación conceptual es importante al momento de aproximar la teoría semiótica a otras disciplinas, a fin de evitar mayores equívocos o imprecisiones teóricas.

En la narratología, la situación es un poco más ambigua. Es bien conocida la postura de Bordwell (1996), quien considera que la figura de un narrador como agente controlador del discurso es por demás innecesaria. Esta afirmación conlleva una serie de problemas desde la misma ontología del discurso. Para empezar, significa obviar que, en tanto acto de creación estético-narrativa, de ninguna manera estamos ante un fenómeno autocatálico. Según Agamben (2019), en todo acto de creación (literario o semejante), la capacidad de poder es inseparable del poder-no: "Si toda potencia es tanto potencia de ser cuanto potencia de no ser, el pasaje al acto solo puede suceder transportando al acto la propia potencia-de-no" (p. 34). Con esto, el autor hace un llamado a los elementos "contingentes" de toda producción estética, los cuales se diferencian de otros que podrían juzgarse "necesarios". Así, la potencia-de-no no es otra potencia que negaría a la primera, sino que se yergue como la inoperosidad que acompaña a cada momento como instancia crítica de la creación: "Hay, en todo acto de creación, algo que resiste y se opone a la expresión". Y continúa: "Lo potencial es, pues, un ser ambiguo, que no solo puede tanto una cosa cuanto su contrario, sino que contiene en sí mismo una íntima e irreductible resistencia" (Agamben, 2019, p. 33). Esto quiere decir que la instancia de enunciación, que toma a su

1 La relevancia de este último no debe subestimarse: "Así entendido, el enunciatario no es solamente el destinatario de la comunicación, sino también el sujeto productor del discurso, al ser la 'lectura' un acto de lenguaje (un acto de significar) muy similar al de la producción, propiamente dicha, del discurso" (Greimas y Courtés, 1990, p. 148). 
cargo la dimensión del saber, no comunica sin más los eventos intradiegéticos, sino que, empleando su poder-no, selecciona cuidadosamente las informaciones que deja fuera del discurso, incluso si al hacerlo omite secuencias cruciales para el enunciatario y su comprensión de la diégesis. Al operar sobre el saber, el enunciador ocupa el lugar de un manipulador informativo regente de la categoría veridictoria (ser/parecer) y del dispositivo de la visión que mencionamos al principio².

Si la operación fundamental del enunciador es proferir enunciados, nada impide que pueda, al mismo tiempo, ocultar muchos otros. Más específicamente, la semiótica greimasiana la inscribe dentro de la categoría del saber del discurso y, por extensión, en la dimensión del creer. El narrador, cuando aparece, opera como personaje en el seno de la diégesis (Prósper Ribes, 1991), pero el actante, aunque no se haga presente, lo está, pues existe presupuesto por el enunciado. En el otro extremo del acto comunicativo, encontramos un espectador-enunciatario susceptible de ser engañado, que el enunciador fílmico pone en la mira.

A la luz de algunos trabajos recientes sobre las competencias cognoscitivas del enunciador fílmico, debemos reconocer el trabajo de Thomas Elsaesser (2009), quien describió la aparición de mind-game films en el panorama cinematográfico, películas que desafían la relación vinculante entre el narrador y el narratario, y, por extensión, desafían también el equilibrio del acuerdo veridictorio implícito entre los actantes de la estructura de la comunicación (Greimas, 1989). Su planteamiento es el siguiente: en una película, la narración se articula desde la perspectiva (en el sentido de la narratología de Genette) de un personaje que posee algún tipo de trastorno mental (amnesia, esquizofrenia, delirio, etcétera) que le hace percibir de un modo erróneo o incompleto el mundo a su alrededor. El narrador (y, por extensión, la narración) no nos indica que el personaje padece esta condición, o bien lo hace de tal modo que deje en claro que, pese a que le es un obstáculo, es fácil de franquear. Sin embargo, al estar focalizados en él o ella, el espectador es incapaz de advertir que, en realidad, lo que ve y lo que escucha el personaje principal es una mentira. Un ejemplo que el mismo Elsaesser (2009) plantea es el de la película El club de la pelea (Fight Club, 1999) de David Fincher, en donde el narrador (intradiegético, que narra su propia historia) entabla una amistad con el personaje de Tyler Durden, sin percatarse de que es un producto de su imaginación. Gran parte del filme transcurre sin que él ni el espectador sospechen que esto es así. El ejemplo es revelador por otra razón. En la película de Fincher, la narración

2 En cuyo caso, debemos recordar a Courtés (1997), para quien el enunciador cinematográfico manipula no solo lo que se ve, sino también, por extensión, lo que no se ve. Un paneo, por ejemplo, descubre una sección del espacio fílmico que antes era ocultado, pero, al hacerlo, debe sopesar el ocultamiento de otra fracción de espacio. El hacer-ver y el hacer-no ver se hallan así en una relación de presuposición recíproca. 
en off recae sobre el protagonista, pero no es competencia suya el mover la cámara ni incorporar la imagen de Tyler al espacio fílmico de la cámara, y, no obstante, su visualización es crucial para que el engaño funcione. Tyler siempre fue un ser imaginario, y esta revelación sorprende tanto al protagonista como al espectador-enunciatario. ¿Quién, entonces, engaña al espectador?

La respuesta que da Elsaesser (2009) es la misma a la que podemos llegar si recordamos las observaciones de Metz (2002), indudable pionero de la semiótica del cine de inspiración saussureana: si el discurso se opone al mundo real es porque, ante todo, es enunciado por alguien. La existencia de una instancia enunciadora previa a la narración se inserta como parte de la ontología misma del discurso. Ahora bien, para poder maquinar su engaño, en el caso de los mind-game films especialmente, el enunciador habrá de trabajar con un simulacro de su enunciatario, un modelo que lo lleve a establecer las marcas veridictorias con las cuales lograr su adhesión, para, al final, sorprenderlo con los estados de cosas intradiegéticos que había deformado. Claro que pecaríamos de ingenuos si dijésemos que la revelación de una mentira supone indefectiblemente su verdad. En efecto: la revelación de la mentira no arroja al enunciatario necesariamente con la realidad de los estados de cosas al interior de la diégesis, sino con otra apariencia de verdad, la cual podría seguir siendo una ilusión segunda, mejor camuflada que la anterior ${ }^{3}$.

El enunciatario se volvería entonces más perspicaz ante la estrategia discursiva del enunciador, más crítico y cauteloso. La violación del contrato fiducial, la revelación abrupta de que lo que se mostró en pantalla (en un caso netamente cinematográfico) era mentira y, aun así, se hizo pasar como verdad, supone un cambio en la actitud del enunciatario. Habiendo depositado su confianza en un enunciador que ha demostrado la competencia y el deseo de mentir, cualquier nueva proposición es tomada con escrutinio por un destinatario receloso, mas no ya adherente (Courtés, 1997). Esto evidencia un punto fundamental: el espacio cognitivo que se establece entre los actantes de la enunciación implica una manipulación e interpretación permanentes, que se inician tan pronto la cámara se ubica ante algo. De esta forma, "al tratar discursos audiovisuales, la posición de la cámara, el aparato tecnológico, dependiente de una elección enunciativa, condiciona las definiciones del saber y de la visión" (Gómez Tarín, 2013, p. 30). La cuestión no debería ser muy diferente si nos situamos al nivel del relato, en donde los actantes de la diégesis manipulan a otros actantes, ocupando ellos mismos, en ese nivel, las posiciones del enunciador y el enunciatario de una comunicación dialógica.

3 Piénsese, por ejemplo, en películas como Inception (2010) de Christopher Nolan, cuya escena última también plantea un final abierto que depende de saber si lo que vemos es real en la diégesis de la película, o si no estamos ante un mero sueño que ni el protagonista llega a advertir. 
En lo que respecta a los actantes de la enunciación propiamente dicha, reconocemos una manipulación que empieza a desarrollarse independientemente de la presencia de un narrador. Anderson (2016) identifica dos posibles tipos de narradores: fidedignos o confiables (reliable) y no fidedignos o desconfiables (unreliable). En línea con esta autora, Hogan (2013) expresa que "un informante no fidedigno es simplemente alguien cuyo discurso lleva a uno a imaginar ciertos aspectos del mundo incorrectamente" (p. 151). Igual que Greimas, el autor identifica el contrato fiduciario como "la base inicial del sentido de confianza o desconfianza del lector o espectador" (Hogan, 2013, p. 154). Esta primera proposición, por lo demás, explica que la confianza en el enunciador sea la actitud inicial de todo proceso narrativo. La sospecha no tiene lugar hasta que se identifica alguna clase de contradicción.

La praxis desinformativa permite taxonomizar a los narradores desconfiables. Se diferencian, entonces, aquellos que subinforman (underreport) y los que contrainforman (misreport) ${ }^{4}$ al espectador-enunciatario (Anderson, 2016). En el primer caso, se está ante un ocultamiento de acontecimientos narrativos por medio de su simple virtualización en discurso; es decir, pudiendo haber sido incorporados a la cadena sintagmática audiovisual, permanecen fuera de ella, más allá de lo que la cámara muestra (como sucede en las películas de misterio, por ejemplo, o en cualquier elipsis que selecciona y deja fuera de la visión algún pasaje de la historia). Es, en resumidas cuentas, un ocultamiento de la verdad. En el segundo caso, el narrador abiertamente incorpora a la narración acontecimientos ilusorios, sin ningún tipo de marcas figurales o figurativas que indiquen su falsedad; es decir, se muestran escenas que parecen verdaderas, pero, en realidad, distan mucho de serlo ${ }^{5}$. Un ejemplo es la película Pánico en la escena (Stage Fright, 1950) de Alfred Hitchcock, donde se muestra un flashback falso que no hace sino desviar la atención del espectador.

La clasificación de la autora parte del supuesto de que la banda de imágenes no está nunca bajo el control de ninguno de los actantes al interior del enunciado, quienes por lo demás ignoran la existencia de la cámara y la dimensión de la enunciación enunciada (Courtés, 1997). La praxis desinformativa, igual que con los mind-game films de Elsaesser (2009), compete tanto al relato como al discurso. Claro está, para el espectador-enunciatario, advertir la praxis es revelar el hacer del enunciador al interior del discurso fílmico. 


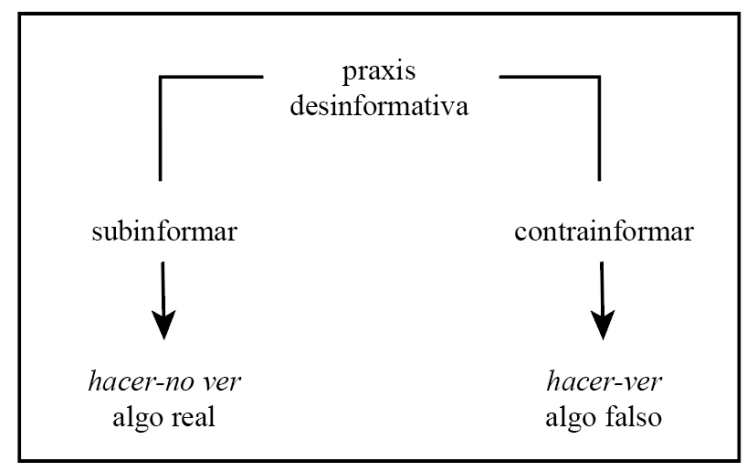

Figura 2. Esquema de la praxis desinformativa

Elaboración propia

Debe entenderse que, en tanto desinformar constituye un hacer del enunciador, este presupone la existencia específica de una competencia. Puntualmente, la competencia del enunciador para subinformar o contrainformar a lo largo del relato, la cual pone en evidencia la inoperosidad de la que habla Agamben (2019): a la potencia de hacer-ver (poder) se le contrapone la de ocultar, hacer-no ver (poder-no). El enunciador se manifiesta, si es que lo hace, a la manera de un narrador competente y astuto que gestiona una comunicación estratégica, y que recuerda (si es que acaso no invoca) a la figura del agente doble, tan discutida por Fabbri (2001). Si este es el caso, estaríamos ante la presencia de un enunciador dispuesto a beneficiar el saber de los actantes-sujetos del relato en detrimento del saber del espectador-enunciatario, solo para luego operar en sentido contrario, beneficiando al segundo a expensas de los primeros. Por lo demás, notar un caso de subinformación o contrainformación, por lo general, es imposible hasta que el enunciatario identifica esa carencia cognitiva de algo que se le escapa 0 , mejor dicho, algo que se le oculta.

Esta extensa recapitulación ha sido necesaria para, por un lado, demostrar las respuestas a la problemática del parecer-ser-verdadero, que resulta transversal tanto a la semiótica discursiva como a la narratología fílmica y que es abordada, en ambos casos, desde la perspectiva de estrategias altamente complejas; $y$, por otro, para exponer la estrecha relación que existe, en el ámbito audiovisual, entre el acto fenoménico de ver y el acto epistémico de creer.

\section{APARIENCIAS Y TRANSFORMACIONES VERIDICTORIAS}

A lo largo de la narración de Los ocho más odiados, los actantes al interior del relato constantemente intentan montar ilusiones para despistar o convencer a otros actantes, 
por lo cual recurrimos al cuadrado semiótico veridictorio para el análisis. Los metatérminos de verdad, falsedad, secreto e ilusión reciben una doble especificación, ya sea que prime el ser o el parecer. En el cuadrado de más abajo, el primer término de la relación es la constante (término especificado) y el segundo es la variable (término especificador), con la muy importante diferencia de que, en cada caso, la variable posee una mayor densidad sémica (Blanco, 2018). De esta forma, cuando algo está oculto, diremos que su modalización respectiva es un [ser.no parecer], pero lo escribiremos como "no parece lo que es", siendo el no parecer la variable y ser la constante. Por el contrario, si aquello que prima es el ser, estamos ante un misterio: "es lo que no parece", o también [no parecer. ser]. La existencia de una barra diagonal (/) señala una especificación recíproca entre la constante y la variable, un punto de equilibrio (Blanco, 2018).

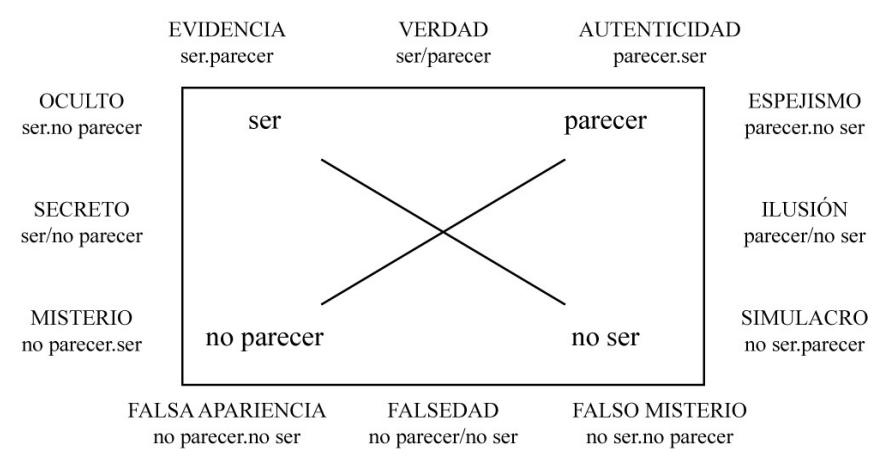

Figura 3. Cuadrado semiótico de la veridicción en su versión ampliada

Fuente: Blanco (2018)

Cuando la diligencia de 0 . B. Jackson se detiene ante el mayor Warren durante una tormenta, su pasajero, John Ruth, demanda que Warren se despoje de sus armas y le explique quién es y qué hace en medio de la nada; el mayor acata y enseña la orden de arresto por los tres hombres que yacen muertos detrás de él. "Actualmente soy un servidor de la corte", afirma el mayor. Más adelante, Ruth le pide que le enseñe la mítica carta que lleva consigo, escrita, supuestamente, por nada menos que el expresidente Abraham Lincoln, y cuya existencia confirma que Warren no solo está del lado de la ley, sino que, en vida, fue un amigo del presidente. A partir de estos documentos, sale a la luz que Warren es y, al mismo tiempo, parece un hombre respetuoso de la ley. En este momento, aquello es una evidencia (parece lo que es). No obstante, cuando más adelante recogen a Mannix en el camino, este discute con Warren sobre la vez que, estando en un campo de prisioneros del sur, inició un incendio para escapar, causando la muerte de soldados confederados y de otros prisioneros unionistas, razón por la cual la Confederación puso una recompensa por él y la Unión lo dio de baja. 
Warren: ¿Se supone que debo sentirme mal por ellos? Tú te uniste a la guerra para mantener negros encadenados. Yo me uní a la guerra para matar granjeros sureños blancos. Eso quiere decir matarlos de cualquier modo que pueda. Dispararles, apuñalarlos, ahogarlos, quemarlos, arrojar una roca en sus cabezas. Cualquier cosa para ponerlos a dormir. Para eso me uní a la guerra, y eso fue lo que hice. (Tarantino, 2015, 0:31:10-0:31:38)

Con esto, John Ruth se desengaña de que la primera etiqueta adjudicada a Warren sea tan transparente como creyó y, porque el enunciador fílmico restringe el punto de vista a este personaje, el espectador-enunciatario se desengaña también. Aunque operando en la legalidad, el mayor Warren no por ello simpatiza con los valores y las formas de vida de un hombre de ley, del mismo modo que tampoco expresa su adhesión por la honestidad o el juego limpio, mientras sus esfuerzos por encubrir su pasado en la guerra salen a la luz. Aun cuando no lo parezca, bajo el inmaculado uniforme de un oficial de la Caballería, se halla, oculto, un asesino amoral y oportunista.

En el caso de Mannix, este se presenta ante la diligencia como el nuevo sheriff de Red Rock, la ciudad a la que el grupo se dirige. No obstante, cuando le piden que enseñe su placa responde que aún no la recibe, por lo que John Ruth desconfía de él desde el inicio. Temiendo que Mannix esté mintiendo, acepta llevarlo, pero le pide a Warren que lo vigile, sospechando que esté confabulado con su prisionera. Es una diferencia sutil, pero importante. A John Ruth no le preocupa que Mannix sea o no el sheriff de Red Rock: sin su placa, da por sentado que esto es falso (no es ni parece). La sospecha proviene de que, aparentando ser un viajero en apuros, en realidad tenga planeado liberar a Daisy. En otras palabras, la inquietud de Ruth proviene de que Mannix no sea lo que parece, o sea, que se trate de un espejismo.

Una vez que el grupo llega a la mercería, la sospecha se expande a prácticamente cada uno de sus ocupantes: Oswaldo Mobray, quien asegura ser el nuevo verdugo de Red Rock, se muestra excesivamente cordial y apegado a los recién llegados. Viéndose interrogado por Ruth, Joe Gage afirma estar yendo a visitar a su madre por Navidad y, mientras tanto, aguarda paciente en su rincón de la mercería. Cuando Bob admite ante Warren que la dueña Minnie y su esposo "Sweet" Dave se hallan fuera visitando a la madre de esta, el exsoldado de la Caballería no desperdicia un instante para sospechar que esto sea falso, dado que, conociéndola desde hace años, Minnie nunca mencionó tener a su madre aún con vida, ni que estuviera al otro lado de la montaña, como Bob asegura.

En ninguno de los casos podemos hablar de un ser convincente; la sospecha es transversal tanto a John Ruth como a Marquis Warren y, por extensión, el espectadorenunciatario sospecha igual que ellos, en la medida en que el enunciador continúa restringiendo el punto de vista a estos dos personajes. Aunque los demás ocupantes se esfuercen en parecer aquello que afirman ser (Oswaldo con sus papeles, Gage escribiendo, Bob cuidando de la mercería), caen bajo la sospecha de Ruth y el especificador 
no ser cobra primacía en la modalidad de espejismo [parecer.no ser]. La sanción cognitiva del mercenario interpretado por Kurt Russell es el no creer en lo que los otros le dicen, lo cual se ve en la conversación que Ruth mantiene luego con Warren, Daisy y O. B. Jackson:

Ruth: Uno de ellos no es lo que dice ser.

Jackson: ¿Y qué son?

Ruth: Cómplices de [Daisy], eso es lo que son. Uno de ellos, quizá hasta dos de ellos, están aquí para asegurarse de que Domergue salga libre. Para conseguirlo matarán a todos los que estemos aquí. (Tarantino, 2015, 1:08:46-1:09:07)

De esta forma, la intriga de la película se construye no sobre la base de si es que hay alguien buscando liberar a Daisy; se trata, más bien, de quién es esa persona, y obliga a los personajes a moverse en el espacio de la ilusión.

En una escena distinta, el enunciador fílmico, figurativizado a la manera de un narrador cuya voz en off proyecta la posición sintáctica del espectador-narratario, confirma que alguien ha envenenado el café y, poco después, Ruth y Jackson mueren al ingerir la bebida. El mayor Warren, quien fue el primero en sugerir que Ruth era un paranoico, interroga a Mannix, Oswaldo, Joe Gage y a Bob a punta de pistola. Deduce, rápidamente, que Mannix no puede haber envenenado el café, pues estuvo a poco de probarlo. De esta forma se comprueba que él es inocente de envenenar a Ruth y a Jackson, y que, siguiendo las funciones veridictorias, es aquello que parece: una víctima más del verdadero asesino.

La escena siguiente expone la interrogación de los otros tres ocupantes de la mercería. Como cualquiera que ocupe el rol temático de un /detective/, el mayor Warren se acerca a su objeto de valor, la /verdad/, mediante deducciones, preguntas y provocaciones. La diferencia es que intencionalmente desvía el interrogatorio y coloca el envenenamiento del café en segundo plano, preocupándose por Bob y la historia que había dicho antes: que Minnie y su esposo Dave se habían marchado, dejándolo a él a cargo. Luego de descubrir la sangre en la silla de Dave, las sospechas de Warren crecen y afirma que Bob no puede haber sido contratado, pues, según dice, Minnie no tolera a los mexicanos, por lo cual es imposible que esto sea verdad.

Warren: A Minnie le caía bien casi todo el mundo, pero con seguridad que no le gustaban los mexicanos. Así que cuando me dices que Minnie se fue al norte para visitar a su madre, encuentro eso muy poco probable. Pero, bueno, quizá sí. Pero cuando me dices que Minnie Mink se fue de la mercería, el objeto más preciado para ella en todo el mundo, ¿y la dejó en manos de un maldito mexicano? A eso me refería en el granero cuando dije que no sonaba como Minnie. Ahora sí te estoy llamando un mentiroso, señor Bob. (Tarantino, 2015, 1:56:03-1:56:51)

En este momento, la constante parecer es negada y emparejada con el especificador no ser, pero la densidad sémica parece nivelarse, no a la manera de una falsa apariencia, 
que supondría la dominancia del no ser; ahora, la constante y la variable cumplen una especificación recíproca en el cuadrado de veridicción. La historia de Bob es falsa en ambos sentidos: no es porque no parece, y no parece porque no es. El no ser y el no parecer son solidarios entre sí. Acto seguido, el mayor dispara y asesina a Bob en frente de todos.

La última transformación la encontramos cuando Warren amenaza con envenenar a Daisy con el café si el responsable no se revela. Joe Gage confiesa su crimen y, antes que puedan hacer algo, un hombre escondido en el sótano de la mercería (a quien luego conoceremos como Jody, hermano de Daisy) le dispara a Warren. En la confusión, Oswaldo saca una pistola de su bolsillo y hiere a Mannix, quien le dispara de vuelta. A partir de aquí, lo que queda de ambos pandilleros es una falsa apariencia [no parecer. no ser] común, ahora, a los ocupantes que conocimos en la mercería. El resumen de las transformaciones que acabamos de señalar se presenta en la tabla 1.

Tabla 1

Resumen de las transformaciones veridictorias de Marquis Warren, Chris Mannix, Bob, Joe Gage y Oswaldo Mobray

\begin{tabular}{cccc}
\hline & Estado inicial & Transformación & Estado resultante \\
\hline Marquis Warren & [s.p]: evidencia & no [p]: ocultación & [s.no p]: oculto \\
Chris Mannix & [p.no ser]: espejismo & no [no s]: autentificación & [p.s]: autenticidad \\
Bob & {$[p . n o s]$ : espejismo } & no [p]: desmitificación & [no p/no s]: falsedad \\
Joe Gage & [p.no s]: espejismo & no [p]: desmitificación & [no p.no s]: falsa \\
Oswaldo Mobray & & & apariencia \\
\hline
\end{tabular}

Elaboración propia

A esto debemos sumarle la performance previa de la banda de Jody cuando llega a la mercería, en palabras del narrador, "más temprano esa mañana". Posando como un grupo de viajeros, se sirven café, deambulan por el lugar, hablan con Minnie, su esposo y sus ayudantes, solo para agarrarlos desprevenidos y asesinarlos a sangre fría, tomando el control de la mercería. El suspenso es evidente, pues, narrado a la manera de un flahsback, el espectador-enunciatario está al tanto de la verdadera identidad de estos personajes, algo de lo cual Minnie y sus allegados no pueden siquiera sospechar. Se advierte, entonces, una disonancia cognitiva entre el saber del enunciatario y el de los actantes del relato: mientras que para el primero los ocupantes de la diligencia son un claro espejismo (no son lo que parecen), los segundos no tienen razón para cuestionar la apariencia, ya que, según ellos, se trata de una auténtica realidad (son lo que parecen). 
Tabla 2

Disparidad veridictoria entre el espectador-enunciatario y los actantes del relato

\begin{tabular}{|c|c|c|}
\hline & espectador-enunciatario & actantes del relato \\
\hline Jody Domergue & \multirow{4}{*}{ [p.no s]: espejismo } & \multirow{4}{*}{ [p.s]: autenticidad } \\
\hline Bob & & \\
\hline Oswaldo Mobray & & \\
\hline Joe Gage & & \\
\hline
\end{tabular}

Elaboración propia

De esta forma, la base epistémica que Greimas (1989) adjudicaba a todo acto de comunicación se lee como una solicitud de contrato y, en el caso de una performance como la que plantea la película, como un ofrecimiento de sí, en donde las expresiones propositivas (yo pienso, yo creo, yo sé) adquieren la forma de un yo soy o un yo aseguro ser, aplicable a la praxis del actante enunciador. Pero el hacer interpretativo que parte de la mirada del otro expone toda sinceridad como efecto de sentido que encubre y, de cierta manera, se esfuerza por hacer transparente el soporte de los signos que es el propio cuerpo, incluso si, al hacerlo, paradójicamente aumenta la sospecha (Groys, 2016), como ocurre con John Ruth y luego con Warren. Es por eso que la densidad sémica ocupa mayoritariamente al no ser, motivando la inquietud y la sospecha de los mercenarios, preocupándolos por el ser encubierto por la apariencia.

\section{SIMULACROS MODALES DE LOS ACTANTES}

El ejemplo más notable de manipulación ocurre hacia el final del tercer segmento. El mayor Marquis Warren decide acercarse al general de la Confederación Sanford Smithers, quien también está en la mercería. Aunque inicialmente cordial, el mayor coloca una de sus pistolas cerca del general y prosigue contando que, hace unos años, tuvo un encuentro con su hijo, Chester Smithers, el cual terminó con este siendo torturado, violado y asesinado por Warren, tras enterarse de que era el hijo de un general racista con varias muertes de soldados negros en su haber. Ante esto, el general toma la pistola e intenta asesinar a Warren, pero él desenfunda y le dispara primero.

Las preocupaciones del espectador-enunciatario sobre la veracidad o falsedad de esta historia son evidentes, sobre todo porque el personaje que la enuncia ha demostrado no ser de fiar. En escenas previas, Warren admitió poseer una carta dirigida a él de Abraham Lincoln, quien asegura que fue su amigo. El documento parece legítimo y le asegura su sitio en la diligencia de Ruth cuando este se lo encuentra. No obstante, Chris Mannix acusa a Warren de fabricar la carta y su historia, algo que el mismo Warren confirma, diciendo que la única razón por la que la tiene es por el efecto que produce sobre otros. 
Warren: No tienes idea de lo que es ser un hombre negro recorriendo América. El único momento en que los negros están a salvo es cuando los blancos no tienen armas. Y esta carta tiene el efecto deseado de desarmar a los blancos.

Ruth: Llámalo como quieras. Yo lo llamo un maldito truco sucio.

Warren: ¿Quieres saber por qué mentí sobre algo como eso, hombre blanco? Me hizo subir a tu diligencia, ¿no es así? (Tarantino, 2015, 1:23:17-1:24:03)

Ese "efecto deseado" es doble. Por un lado, parecer-ser-verdad, y luego, querer-no hacer, neutralizar la agresión virtualizada. Los sujetos virtuales, una vez convencidos de la veracidad de la carta, desisten de cualquier hostilidad hacia Warren, asumiendo que están ante un hombre de confianza del presidente. Solo posteriormente se instaura en ellos un querer-hacer complementario, es decir, querer ver la carta, o bien hacer favores para que el exoficial de la Unión se las enseñe (por ejemplo, que John Ruth deje que suba a su diligencia). Como todo buen manipulador, Warren monta un simulacro modal de aquellos con los que entra en contacto, creyendo que la carta los hará desistir de toda agresión, y, acto seguido, creyendo que los demás querrán verla, algo más que predecible con Ruth, pues, como él mismo dice, ya ha tenido la oportunidad de leer la carta en un encuentro anterior, y en ese entonces le pareció legítima.

S1 creer/saber $\{\text { S2 creer (parecer-ser: "la carta es real") }\}^{6}$

S1 creer/saber \{S2 creer (no querer-hacer: "no hacer daño")\}

S1 creer/saber \{S2 creer (querer-hacer: "querer ver la carta")\}

S1 = Marquis Warren $\quad$ S2 = John Ruth

De la misma manera, Ruth se acerca precavidamente a todo el que cruce su camino hasta Red Rock, creyendo que podrían ser cómplices de su prisionera o, en todo caso, que puedan liberarla de él para ganarse la recompensa:

S1 creer [S2 creer (poder-hacer: "llevarse a Daisy")]

$\mathrm{S} 1=$ John Ruth $\quad \mathrm{S} 2=$ extraños en el camino

El altercado con el general Smithers que describimos al inicio no escapa a la necesidad de montar un simulacro modal del enunciatario por parte de Warren. Este quiere asesinar a Smithers, pero le advierten que, de hacerlo, irá preso por homicidio, y decide tentarlo para que él arremeta primero. Pero, de momento, el hombre no desea asesinar a Warren, además de que carece de los medios para hacerlo.

6 El simulacro se lee de la siguiente forma: “Marquis Warren (S1) cree que John Ruth (S2) cree que la carta parece y es real". Los demás simulacros operan de la misma manera. 
Para lograr su objetivo, Warren modaliza a Smithers para que este quiera cobrar venganza por su hijo. Primero, deja una de sus pistolas en la silla del general, y así este último obtiene los medios para poder asesinarlo. La historia de la muerte de su hijo constituye un saber que Smithers juzga verdadero, incluso cuando su única evidencia es la palabra de su manipulador. Finalmente, cuando la historia ha concluido, la proximidad física con Warren deviene en la instalación de un querer específico (la venganza), motivado, en gran medida, por las provocaciones de este último:

Warren: ¿Y qué piensas hacer, viejo? ¿Vas a pasar los próximos dos o tres días ignorando al negro que mató a tu hijo? ¿lgnorando cómo lo hice sufrir? (Tarantino, $2015,1: 34: 03-1: 34: 38)$

Siguiendo la notación del programa narrativo (PN), el proceso de modalización se grafica de la siguiente manera:
$\mathrm{PN} 1[\mathrm{~S} 1=>(\mathrm{S} 2 \Lambda \mathrm{Omp})]^{7}$
"Warren le da el arma a Smithers."
$\mathrm{PN} 2[\mathrm{~S} 1=>(\mathrm{S} 2 \wedge \mathrm{Oms})]$
"Warren le cuenta la historia a Smithers."
$\mathrm{PN} 3[\mathrm{~S} 1=>(\mathrm{S} 2 \wedge \mathrm{Omq})]$
"Warren tienta a Smithers para que él lo asesine."

$\mathrm{S} 1=$ Warren $\quad \mathrm{S} 2=$ Smithers

Objeto modal del poder $=$ pistola $\quad$ Objeto modal del saber $=$ historia

Objeto modal del querer $=$ Warren

Ofreciéndose a sí mismo como objeto de la venganza, el proceso manipulatorio de Warren adquiere la modalidad de una tentación. El resultado, según lo anticipa el mismo Warren, es la performance fallida del general y la sanción pragmática que lo lleva a dispararle de vuelta, acabando con la vida de Smithers en defensa propia, dentro del margen de la ley. En realidad, el exoficial de la Unión nunca pretendió darle a Smithers el poder de asesinarlo. Entregarle la pistola es un falso poder, la ilusión de una competencia. Lo importante para Warren, más bien, era que el general creyera tener el poder de asesinarlo. En términos modales, su objetivo era el creer poder de su enunciatario, en cuyo caso el primer término de la modalidad (el creer) tiene una densidad sémica mucho mayor respecto al segundo. El simulacro modal le permite anticipar el fracaso de la acción y, por consiguiente, prever el éxito de la suya. En el simulacro final de Warren, la modalidad del creer adquiere una importancia capital:

7 “Warren (S1) le da la pistola (Omp) a Smithers (S2)". El símbolo $\Lambda$ denota un estado de conjunción entre el sujeto y el objeto modal. 
S1 creer [S2 creer (querer-hacer/poder-hacer: "querer/creer poder dispararle a Warren")]

S1 = Marquis Warren

S2 = Sanford Smithers

La secuencia, sin embargo, funciona por algo más. A la pregunta de por qué Smithers confiaría en la palabra de Warren se suma el hecho de que el primero ha demostrado ser garante de un creer ingenuo. En este ámbito, el relato construye a Smithers como garante de una forma de vida para nada beneficiosa: el inocente, alguien que "no sabe lo que cree" y por ello toma por verdadero lo que se le dice (Dorra, 2016, p. 18). Esto coloca al personaje como la antítesis de la figura del escéptico, aquel que sistemáticamente pone a prueba su creer y desconfía de lo que se le dice (como es el caso de John Ruth).

Ello explicaría por qué, cuando Jody le ofrece dejarlo con vida si tienen éxito rescatando a Daisy, Smithers acepta sin mayores garantías de que el pandillero cumplirá su palabra. Así, la desconfianza inicial de un manipulador se ve correspondida por la voluntad de creer de un manipulado que cree sin saber, a quien paradójicamente "no se le puede dar confianza, en la medida en que sus creencias no son selectivas" (Fontanille y Zilberberg, 2004, p. 231). De hecho, empleando términos de Dorra, se trata de un creer que creo, lo cual manifiesta, en lugar de una creencia firme y razonada, un deseo-de-creer o de saber: en el primer caso, querer creer que si obedece saldrá con vida; en el segundo, querer saber cómo murió su hijo y, por extensión, creer en lo que se le dice, incluso si la respuesta es abominable.

\section{LA PRAXIS DESINFORMATIVA: EL NARRADOR DESCONFIABLE}

Advertimos ahora la utilidad de los aportes de la narratología respecto al discurso. Las ideas de Elsaesser (2009) y Anderson (2016) tienen algo en común: el enunciatario ${ }^{8}$ parte de una posición inicial de confianza en el narrador fílmico, una predisposición a creer en lo que este le muestra, creyéndolo incapaz de mentirle. Para maquinar su engaño de manera coherente, el narrador ha de incorporar esto a un simulacro, el cual podemos plantear con la siguiente función:

\section{S1 creer \{S2 creer [S1 creer (no poder-hacer: "no poder mentir")]\} \\ $\mathrm{S} 1=$ enunciador/narrador fílmico $\quad \mathrm{S} 2$ = enunciatario/narratario fílmico}

Como se observa, el simulacro ubica al narratario (es decir, al espectador) en la posición de un crédulo, para quien ver equivale en muchos casos a creer y el saber se

8 Optamos por mantener esta terminología en detrimento de la pareja narrador/narratario, en correspondencia con la teoría semiótica, donde la narración también se halla bajo el control de la instancia de enunciación (Blanco, 2012). 
desprende, indefectiblemente, de las acciones y acontecimientos del relato (GarcíaNoblejas, 1983), los cuales el narrador fílmico (primer actante desembragado de la instancia de enunciación) manipula, ofrece y oculta según mejor le parezca.

Un caso de subinformación (underreport) ocurre al inicio del capítulo cuatro, llamado "Domergue tiene un secreto". Luego de una breve elipsis y el intertítulo que nombra el segmento, una voz en off explica que han pasado quince minutos desde que Warren asesinó a Smithers, y que todos en la mercería están distraídos con diferentes actividades, excepto Domergue, quien, como el título de la escena manifiesta, está ocultando algo. Entonces pasamos a un flashback de la escena donde Warren dispara contra el confederado, pero desde una perspectiva distinta. La voz, mientras tanto, describe la imagen con lo siguiente:

Narrador (en off): Volvamos un poco más atrás. Hace quince minutos, el mayor Warren le disparó al general Smithers en frente de todos. Pero cerca de cuarenta segundos antes pasó algo igual de importante, aunque no todos lo vieron. Mientras Warren cautivaba a su audiencia con historias de penes negros y bocas blancas, alguien envenenó el café. Y la única persona que lo vio hacerlo... fue Domergue. Por eso este capítulo se llama "Domergue tiene un secreto". (Tarantino, 2015, 1:36:36-1:37:29)

En la secuencia, el narrador fílmico abiertamente regresa sobre los acontecimientos que acaban de mostrarse, revelando al espectador-narratario un saber que hasta entonces le era desconocido. Es más, un secreto que no sabía que ignoraba. La secuencia, por lo demás, revela la capacidad de presentación de acontecimientos narrativos (poder), y la inscribe al mismo nivel junto con la competencia por ocultar información (poder-no), cuya configuración modal resulta solidaria con las formulaciones de Agamben (2019). La inoperosidad, por ende, está implícita en la operosidad del acto de creación estético-narrativo o, más específicamente, en el acto narrativo y discursivo que la instancia regula.

Más intrigantes son las operaciones efectuadas al nivel de la enunciación, que se ponen de manifiesto cuando Warren cuenta su historia. Luego de que admite haber conocido al hijo de Smithers, la banda de imágenes muestra a Chester Smithers en un prado cubierto por la nieve, con ambas manos en alto, rogando por su vida. El montaje entonces regresa a la escena de la mercería. Poco después, Warren describe que lo hizo desnudarse y caminar a temperaturas bajo cero por dos horas; la imagen acompaña su discurso, haciendo ver al espectador-enunciatario la escena que el personaje describe. Ahora bien, ningún actante-personaje que exista al nivel del relato puede manipular la banda de imágenes, por la sencilla razón de que el primero refiere al relato y la segunda al discurso. Esta operación recae en el enunciador propiamente dicho, es decir, el enunciador fílmico, el mismo que luego se muestra de manera simulada, a 
través de intertítulos, subtítulos y voces en off. El acto de enunciar una rememoración, por parte del personaje, es una competencia muy distinta al acto de insertar en el eje sintagmático de la película fragmentos de aquello que se recuerda. Lo segundo ocupa únicamente al enunciador y, desde una pertinencia más amplia, al hacer de una instancia semiolingüística. En este ámbito, el pensamiento de Anderson (2016) es solidario con las formulaciones de la semiótica estructural:

Un espectador puede entender que un flashback provenga del punto de vista de un personaje, pero nunca asumiría que ese personaje ha puesto esa secuencia en su lugar. [...] Ningún personaje puede, a voluntad, abrirse paso entre barreras diegéticas para reemplazar o siquiera manipular al narrador, quien por su cuenta es capaz de presentarle eventos al espectador. (p. 85)

No obstante, Warren se ha mostrado ya desempeñando el rol de un manipulador, al mismo tiempo que, como él mismo admite, tiene el hábito y la facilidad de mentir para conseguir lo que quiere. ¿Qué asegura que su historia con el hijo de Smithers sea verdadera? Porque el espectador la puede ver, se dirá. Porque proviene del enunciador y este no nos engaña. Pero es exactamente esto lo que advierten los textos de Anderson (2016) y Elsaesser (2009): el enunciador fílmico es capaz de ocultar información (underreport), así como presentar información falsa (misinform) y abiertamente mentirle al espectador-enunciatario a través de un personaje que, según se observa, no ha demostrado ser confiable?. De este modo, el enunciador fílmico manipula al espectadorenunciatario estableciendo las marcas veridictorias del parecer-ser de un flashback, pero nada asegura que los acontecimientos narrados por Warren hayan ocurrido al interior de la diégesis. La verdad o falsedad de su historia es por demás ambigua. En tanto los insertos de la tortura de Chester provienen del discurso de un personaje cuya credibilidad ha sido ya puesta en duda, el enunciador/narrador fílmico demuestra estar, ahora, del lado de este personaje desconfiable, tratando de convencer al enunciatario del mismo modo que Warren convence a Smithers. Igual que en Pánico en la escena de Hitchcock, el flashback podría ser falso, un caso de contrainformación.

Si bien en esta escena el enunciador fílmico respalda a Warren, en la siguiente se pone en su contra, lo contradice. El capítulo cinco "Los cuatro pasajeros" discurre a la manera de un extenso flashback en el que, como ya dijimos, la banda de Jody asesina a los ocupantes de la mercería y convence a Smithers de que los ayude en su trampa. En esa misma escena, el personaje de Bob se presenta ante Minnie y revela que es mexicano,

9 Anderson (2016) describe detalladamente esta operación focalizadora: “El narrador cinemático, entonces, es desconfiable en el sentido en que adopta el punto de vista de un focalizador poco confiable como si fuese preciso, y por ende es al narrador cinemático al que debemos culpar por contrainformar. [...] Estos personajes son 'focalizadores' en tanto [el espectador] ve aquello que ellos nos hacen ver. Los eventos a través de ellos como a través de la cámara" (p. 89). 
pero ella no se inmuta al respecto. Esto contradice aquello que Warren mencionó en el capítulo anterior: que Minnie no toleraba a los mexicanos. La información presentada indica que, a todas luces, el racismo de la dueña de la mercería en realidad era otra mentira de Warren, cuya única intencionalidad era probar al personaje de Bob y que se delate como un impostor. Asumiendo que la narración no se contradice a sí misma (Hogan, 2013), la única explicación es que el personaje de Samuel L. Jackson estaba mintiendo, mientras que el enunciador fílmico, si bien antes permitió que el engaño llegase a nosotros, ahora expone la verdad. Si el espectador-enunciatario había creído en la palabra de Warren, se le demuestra que había pecado de ingenuo.

La secuencia permite manifestar una de las mayores preocupaciones temáticas de la narración de Los ocho más odiados, cuando no de toda la filmografía de Tarantino. Sin la necesidad de la adecuación entre las palabras y las cosas (o, en nuestro caso, entre las imágenes y los discursos intradiegéticos), los actos discursivos fundamentan su propio efecto de verdad (Agamben, 2017, 2019; Greimas, 1989). Esta cuestión concierne tanto a la enunciación cinematográfica y a la figura del narrador fílmico como a los actantes que coexisten al interior de la diégesis. En ciertos casos, el enunciador auxilia a estos últimos con imágenes que permiten el efecto de sentido de parecer-ser verdadero; en otros, se empeña en contradecirlos. Evidentemente, las imágenes no se dirigen a otros personajes, sino al destinatario presupuesto de la enunciación fílmica, es decir, al espectador-enunciatario (Courtés, 1997; Anderson, 2016). Incorporar esta instancia a su estrategia discursiva hace posible que el enunciador opere sobre la base de simulacros modales, ciñéndose a un muy astuto juego de las apariencias en el que el enunciatario se ve implicado.

\section{PARA TERMINAR: LA CRISIS DE LA FIDES}

La narración de la película trabaja con actantes que demuestran ser extremadamente competentes en su hacer, ya sea que se les ubique al nivel de la enunciación enunciada o del relato en sentido estricto. La /desconfianza/ como construcción isotópica se extiende incluso más allá de las fronteras de lo narrado, del enunciado-enunciado, y obliga al espectador-enunciatario a depender de un narrador que, igual que sus personajes, manifiesta su capacidad de engañar, ocultar e inventar información. A veces del lado de los personajes, a veces en su contra, lo cual no equivale a decir que beneficie el saber del espectador-enunciatario, pues también se aprovecha de él mediante su simulacro (Fontanille y Zilberberg, 2004). Ante esta evidencia, debe reinterpretarse el plano inicial de la película, el cual, en apariencia, guarda poca relación con los acontecimientos de la narración. Luego de presentar el título, la cámara corta a un crucifijo de madera, el cual se halla en medio de un llano nevado y que, debemos asumir, terminará por ser cubierto cuando la tormenta haya terminado. De lejos, aparece la diligencia de John Ruth, pasando junto al Cristo tallado en su camino a la mercería, dándole la espalda y alejándose de él. 
La imagen de un Jesucristo moribundo, desapareciendo entre la nieve, está lejos de ser gratuita. Apoyado en textos de origen clásico, Agamben (2017) refiere a la fides como institución elemental en la convivencia de los seres humanos, ya sea que se la entienda como un abandonarse-al-otro (confiar en alguien) o un crédito-de-sí (inspirar confianza). Según el filósofo, "aquella experiencia del lenguaje de la que no podemos dudar" es el juramento, en la medida que, cuando uno jura, el lenguaje humano comulga con el divino, con /Dios/, lexema que "nombra el nombre que es siempre y solo verdadero". Desde esta perspectiva, "hablar es, ante todo, jurar, creer en el nombre" de Dios (p. 87). Transgredir la palabra dada, mentir, engañar o, en general, violar la fides, implica de manera obligada blasfemar el poder del nombre divino que da credibilidad al juramento. En este ámbito, tiene sentido que el Cristo de madera del inicio esté de espaldas a los protagonistas, quienes se alejan de él para adentrarse en un territorio donde la palabra, en lugar de mantener la fides, la niega.

La situación demuestra ser verdaderamente crítica si advertimos la relativa independencia del simulacro del enunciador, dispuesto a desmentir a los actantes del relato habiéndoles apoyado previamente, o, en lo que refiere al enunciatario, a veces de su lado, a veces en su contra. He aquí donde, tal vez, nos encontramos con una de las observaciones de Fabbri (2001), quien hace más de dos décadas advertía sobre la absolución de lo verdadero y de lo falso como tal, dejando tras de sí actantes "inmersos en la reversibilidad enigmática de las apariencias" (p. 125). Esta cuestión, crítica en las sociedades posindustriales, parece extenderse al ámbito del discurso narrativo, integrándose a la competencia del actante enunciador. Su hacer sobre la dimensión del discurso demuestra no tener más límites que los del discurso-enunciado, manipulando hábilmente la narrativa y, como dijimos al inicio, las categorías ser y parecer de la categoría veridictoria.

\section{REFERENCIAS}

Agamben, G. (2017). El sacramento del lenguaje. Adriana Hidalgo editora.

Agamben, G. (2019). Creación y anarquía. Adriana Hidalgo editora.

Anderson, E. (2016). Telling stories: unreliable discourse, Fight Club and the cinematic narrator. Journal of Narrative Theory, 40(1), 80-107.

Blanco, D. (2012). Vigencia de la semiótica y otros ensayos. Universidad de Lima, Fondo Editorial.

Blanco, D. (2018). Semiótica del texto fílmico. Universidad de Lima, Fondo Editorial.

Bordwell, D. (1996). La narración en el cine de ficción. Paidós.

Branigan, E. (1992). Narrative comprehension and film. Routledge. 
Casetti, F. (1996). El film y su espectador. Cátedra.

Courtés, J. (1997). Análisis semiótico del discurso: del enunciado a la enunciación. Gredos.

Dorra, R. (2016). Modos y grados del creer. Tópicos del Seminario, 36(2), 13-45.

Elsaesser, T. (2009). The mind-game film. En W. Buckland (Ed.), Puzzle films: complex storytelling in contemporary cinema. Wiley-Blackwell.

Fabbri, P. (2001). Tácticas de los signos. Ensayos de semiótica. Gedisa.

Fontanille, J., y Zilberberg, Cl. (2004). Tensión y significación. Universidad de Lima, Fondo Editorial.

García-Noblejas, J. J. (1983). Poética del texto audiovisual. Ediciones Universidad de Navarra.

Gaudreault, A., y Jost, F. (1995). El relato cinematográfico: cine y narratología. Paidós.

Gómez Tarín, F. (2008). Saber y mirar. Una propuesta de reformulación de los conceptos de focalización y ocularización en los discursos audiovisuales. En Actas del Congreso Internacional Fundacional de la Asociación Española de Investigación de la Comunicación (AE-IC).

Gómez Tarín, F. (2013). El punto de vista en el audiovisual contemporáneo: una reformulación de conceptos enunciativos y narrativos. En M. Álvarez (Ed.), Imágenes conscientes (pp. 27-45). Orbis Tertius.

Greimas, A. J. (1989). Del sentido II. Ensayos semióticos. Gredos.

Greimas, A. J., y Courtés, J. (1990). Semiótica. Diccionario razonado para una teoría del lenguaje (vol. 1). Gredos.

Groys, B. (2016). Bajo sospecha. Una fenomnología de los medios. Pre-Textos.

Hogan, P. (2013). Narrative discourse. Authors and narrators in literature, film, and art. Ohio State University Press.

Metz, C. (2002). Ensayos sobre la significación en el cine (1964-1968) (vol. 1). Paidós.

Prósper Ribes, J. (1991). El punto de vista en la narrativa cinematográfica. Fundación Universitaria San Pablo CEU.

Prósper Ribes, J. (2013). El sistema de continuidad: montaje y causalidad. Historia y Comunicación Social, 18, 377-386.

Stam, R., Burgoyne, R., y Flitterman-Lewis, S. (1999). Nuevos conceptos de la teoría del cine: estructuralismo, semiótica, narratología, psicoanálisis, intertextualidad. Paidós.

Tarantino, Q. (director). (2015). Los ocho más odiados [película]. The Weinstein Company. 